\title{
RECENZJE
}

\section{Wokół współczesnych interpretacji filozofii Kanta}

\author{
Kant v kontextoch Husserlovej a Heideggerovej filozofie. \\ Eds. V. Leško, Z. Plašienkowa. \\ Acta Facultatis Philosophicae Universitatis S̆afarikianae 4, \\ Košice 2009, ss. 304.
}

Zadanie, które postawili sobie redaktorzy książki może wydawać się banalne. Chodzi bowiem o pokazanie, że Kant wciąż stanowi punkt odniesienia dla filozofii współczesnej. Oczywistość tego założenia nie wyklucza wcale, że ów problem jest dostatecznie rozpoznany. Przeciwnie, recepcja Kantowskiego krytycyzmu w filozofii XIX i XX wieku wciąż wymaga szerszych badań. Redaktorzy, zapewne także po to, by nadać książce spójny charakter, dookreślili temat, który mówi o Husserlowskich i Heideggerowskich kontekstach myśli Kanta. Warto w tym miejscu wspomnieć, że autor Bycia i czasu od samego początku swej naukowej kariery, a Husserl w zasadzie dopiero po Badaniach logicznych na poważnie zainteresowali się filozofem z Królewca. Trudno dziś bez tego Kantowskiego horyzontu w pełni zrozumieć ich koncepcje. Jest zatem co badać i już samo sformułowanie tematu książki warte jest docenienia.

Książka jest wynikiem konferencji międzynarodowej, która odbyła się w 2008 roku w Koszycach. Co ciekawe, jak piszą we Wstępie Vladimir Leško oraz Zlatica Plašienková, była to pierwsza konferencja na ziemi słowackiej poświęcona filozofii Immanuela Kanta. W trakcie tego historycznego wydarzenia, w którym brali udział filozofowie ze Słowacji, Czech i Polski, miało miejsce znaczące wydarzenie. Uniwersytet Pavla Jozefa Šafarika w Koszycach nagrodził doktoratami honoris causa dwóch wybitnych filozofów. Bez wątpienia owo zaszczytne wyróżnienie trafiło w godne ręce. Wkład słowackiego filozofa, a przy tym znakomitego tłumacza Teodora Münza oraz czeskiego filozofa, badacza niemieckiego idealizmu Milan So- 
botki w badanie i propagowanie filozofii niemieckiej na Słowacji i w Czecha jest imponujący. Nie zabrakło zatem na konferencji uroczystych laudacji, przemówień i gratulacji, co także zostało udokumentowane w recenzowanej książce. Ale przyjrzyjmy się nieco bliżej najważniejszej część książki, czyli zebranym artykułom.

Teksty zebrane w tomie dotyczą różnych aspektów filozofii Kanta. Należy więc dokonać krótkiego podsumowania. Warto jednak pamiętać, że książka nie jest monografią o Kancie, świadomie pomija szereg problemów poruszonych w jego twórczości. Zebrane artykuły pozwalają jednak na ocenę określonych filiacji między autorem Krytyki czystego rozumu a filozofią Husserla oraz Heideggera. I tak mamy tutaj niezwykle ciekawe studia Sobotki i Münza - które choć nie wykraczają poza analizę samego Kanta - to jednak skupiają się na tym, co najważniejsze, a zaraz w najbardziej żywe i aktualne w jego filozofii tj.: na problemie metafizyki i etyki. Teksty te miały stanowić w pewnym sensie wprowadzenie do dalszych artykułów, i z tego zadania wywiązują się znakomicie. Głównym tematem artykuł Milana Sobotki Kant $i$ metafizyka jest tu stosunek Kanta do metafizyki, który Sobotka określa jako metakrytyczny. Kant jest jednym z najważniejszych krytyków starej metafizyki, chociaż w pewnym sensie jest także jej obrońcą - wykazując mianowicie, że przedmioty starej metafizyki nie są zwykłą konstrukcją rozumu, lecz są transcendentalnie uwarunkowane. Autor przedstawia transcendentalne założenia koncepcji przedmiotów metafizyki, gdzie funkcją idei ma być syntetyzowanie naszego poznania tak, by stanowiło ono jedność ufundowaną na czymś nieuwarunkowanym. Na praktyczną stronę filozofii Kanta zwraca uwagę Teodor Münz (Kant a myślenie praktyczne). Autor próbuje pokazać na czym polega aktualność filozofii praktycznej Kanta. Tak, jak wszelkie poprzednie teorie moralności zakładały swój cel w zmysłowości, pożytku, rozkoszy, szczęściu itd., tak Kant proponuje nowe stanowisko. Czysty rozum, zwrócony już nie w stronę spekulacji, ale do praktycznego życia, rozum, który wcześniej tylko poznawał, a który teraz mówi nam jak mamy się zachowywać, staje się czystą wolą.

Drugą grupę stanowią artykuły - dodam, że znakomicie udokumentowane historycznie - wskazujące na wciąż nie do końca wyjaśnioną rolę poprzedników Kanta w kształtowaniu się fenomenologii transcendentalnej. I tak analizę kilku odmiennych projektów zreformowania metafizyki w filozofii niemieckiego Oświecenia przedstawia Radosław Kuliniak w artykule Problem i reforma metafizyki w filozofii niemieckiego Oświecenia w drugiej połowie XIX wieku. Historia rozpoczyna się od konkursu ogłoszonego przez Królewską Akademię Berlińską, gdzie swe prace złożyli m.in. Mendelssohn, Kant czy Lambert. Autor omawia propozycje, cele i zadania, które stawiali przed metafizykę konkursowicze, podkreślając przy tym znaczącą rolę i wpływ Lamberta na przedkrytyczną reformę metafizyki Kanta.Oryginalna metoda metafizyki Kanta w korespondencji z Lambertem i jej dogmatyczna dekonstrukcja u Heideggera - tak brzmi tytuł artykułu Břetislava 
Horyny. Wnikliwie i rzeczowo przedstawiając nie tylko historyczne, ale także systematyczne założenia dialektyki transcendentalnej, autor ukazuje jej ważność w systemie filozofii Kanta. Z drugiej strony zaznacza, że Heidegger zupełnie nie dostrzegł tego faktu, przez co jego krytyka filozofii transcendentalnej Kanta była nieproduktywna, więcej, Horyna ukazuje nieadekwatność ontologii fundamentalnej z filozofią Kanta. O ważność Leibniza w perspektywie współczesnych dyskusji nad metafizykę upomina się Peter Nezník (Heidegger, Kant, Leibniz czyli walka o metafizykę). Autor Monadologii w wyjątkowy sposób łączył tradycję ze współczesnością - budujacc największą syntezę metafizyczną, a także stając się główny architektem współczesnej wiedzy naukowej. Nezník uważa, iż projekt Leibniza choć tylko w części, to jednak był kontynuowany przez Kanta i Heideggera.

Następnie wyodrębnić można teksty, które odnoszą się do recepcji filozofii Kanta. Motyw filozofii pierwszej w fenomenologii Husserla zainteresował Czesława Głombika (Droga Husserla do filozofii pierwszej). Problematyka filozofii pierwszej, choć ujawniała się stopniowo, to jednak w ostatnim okresie fenomenologii Husserla stała się jednym z najważniejszych tematów. Jak trafnie wykazuje autor tekstu, zadaniem jej jest ufundowanie krytyki rozumu na absolutnie pewnych podstawach czystej świadomości. Nie bez znaczenia dla krystalizowania się filozofii pierwszej były także studia późnego Husserla nad dziejami filozofii. Do zagadnienia filozofii dziejów nawiązuje także następny artykuł, w którym Vladimír Leško (Heidegger, Kant $i$ metafizyka) rozpatruje związek między Kantem i Heideggerem. Filozofia Kanta jest jednym z najważniejszych punktów odniesienie dla autora Bycia $i$ czasu. Owa relacja nie ogranicza się jedynie do wczesnej fazy filozofii Heideggera, nie skupia się również wyłącznie na problematyce metafizycznej. Heidegger wykorzystuje interpretacje filozofii Kanta do tego, by wyraźnie zdystansować się tak od Husserla, jak i od neokantyzmu. Fundamentalny problem filozofii Heideggera: kwestia bycia, choć nie zrodzona ani z fenomenologii Husserla, ani z filozofii Kanta, to jednak w konfrontacji z ich filozofią nabiera nowego - historycznego - znaczenia. O kontrowersjach wokół rozumienia filozofii Kanta, które pojawiły się natychmiast po ukazaniu się pierwszego wydania Krytyki czystego rozumu, traktuje wartościowy artykuł Andrzeja J. Norasa (Kant w sporach o metafizyke w XIX wieku). Spór o metafizykę Kanta, bo na tym koncentruje swe rozważania autor, zdeterminowała dyskusja nad rzeczą samą w sobie. Autor rozpatrujacc liczne przykłady (m.in. J. Volkelta) podkreśla, że przedmiotem dyskusji była przede wszystkim kwestia rozumienia rzeczy samej w sobie i doświadczenia. Problem istnienia rzeczy samej w sobie (ontologiczne pytanie o byt) stał się przedmiotem późniejszych rozważań m.in. N. Hartmanna i Heideggera. W kolejnym tekście Pavol Tholt (Husserl, Kant i matematyczne przyrodoznawstwo. O logicznych i metafizycznych aspektach Kantowskiej koncepcji matematycznego przyrodoznawstwa) rozpatruje jeden z często dyskutowanych problemów w ramach logicznych i matematycznych 
nauk - kwestię założeń matematycznego przyrodoznawstwa. Autora zajmuje nie tylko historyczne użycie tego terminu w dziełach Kanta i Husserla, ale także jego logiczne podstawy - w tym ufundowanie matematycznego przyrodoznawstwa na filozofii transcendentalnej. Ostatni artykuł w tomie nawiązuje ponownie do Heideggera. W swym tekście Štefan Jusko (Heidegger $i$ estetyka transcendentalna Kanta) ocenia krytykę estetyki transcendentalnej przeprowadzonej przez Heideggera. Jusko zwraca uwage na zasadność Heideggerowskiej krytyki zarzucającej Kantowi niedostateczne rozjaśnienie relacji czasu do przestrzeni i ruchu, a stąd nie dość precyzyjne rozjaśnienie tego, co transcendentalne.

Dwa, spośród przedstawionych tekstów interesująco poszerzają temat podjęty w książce. Celem Stanislava Hubíka w jego „napisanym” tekście Grafika i krytyka. Estetyka transcendentalna a kinestetyka było odczytanie poglądów Kanta i Husserla w kontekście gramatologii Derridy. Głównym problemem, który przedstawia Hubík jest charakterystyka relacji między językiem, pismem a mową, gdyż aby filozofia zaistniała, musiał pojawić się tekst, który nie powstałby, gdyby nie było pisma, ono z kolei jest dlatego, że istnieje rzecz. Z kolei czeski filozof Jan Zouhar w swoim studium Patočki rozumienie pojęcia czasu u K. H. Máchy - Kant, Husserl, Heidegger podejmuje relację między największym przedstawicielem czeskiego romantyzmu i największym czeskim filozofem. Choć może się wydawać, że dla Patočki miało ono jedynie charakter marginalny, to jednak - jak dowodzi Zohuar - w istocie jest zupełnie inaczej. I tak na przykład w 1944 roku napisał tekst dotyczący symbolu ziemi u Máchy, bezpośrednio odnosząc tę metaforę do ówczesnych losów narodu czeskiego. Patočka nie ograniczał się wyłącznie do interpretacji samej poezji, lecz równocześnie prezentował jej główne pojęcia (czas, czasowość, wieczność) w perspektywie koncepcji Kanta czy Heidegger.

Na szczególną uwage zasługują dwa artykuły, obydwa napisane przez młodych słowackich filozofów. W pierwszym z nich Eugen Andreanský (Kant i Husserl o formalizmie i psychologizmie w logice) rozważa filozoficzną relację między Kantem i Husserlem w odniesieniu do problemu psychologizmu. Krytyka psychologizmu, która w XIX wieku stanowi także podłoże dla kształtowania się logiki współczesnej, znajduje swoje miejsce w Badaniach logicznych Husserla. W argumentacji Husserla nie trudno odnaleźć wpływy Fregego. Czy także Kanta? Autor podkreślą istotną rolę Kantowskiej logiki w kształtowaniu się logiki współczesnej, przekonując, że można taki wpływ uzasadnić. Tekst Andreanský'ego akcentuje logiczną stronę filozofii Kanta, która jest w zasadzie kontynuowane przez Husserla. Owo zastrzeżenie dotyczy raczej kwestii historycznej, gdyż autora Badań logicznych przyznawał się raczej do tradycji Leibniz-Bolzano-Lotze, aniżeli Kantowskiej.

W drugim wyróżnionym artykule - Kant, Husserl a problem dziejów - Milovan Ješič próbuje zrekonstruować filozofię dziejów Kanta i Husserla. Słowacki filozof dowodzi, że ambicją Kanta było odnalezienia w dziejach apriorycznych za- 
łożeń, za pośrednictwem których dzieje mogłyby się urzeczywistnić. Husserl z kolei w swym wczesnym okresie dystansował się od perspektywy historycznej, dopiero w Kryzysie zmierza do ukazaniu a priori dziejowości w ogóle, dokonując przedstawienia dziejów jako żywego ruchu uniwersalnego sensu. Tekst Ješiča znakomicie wpisuje się w szeroki projekt realizowany pod kierunkiem Vladimíra Leški na Uniwersytecie w Koszycach, dotyczący filozofii dziejów filozofii, czyli filozoficznej refleksji nad historią filozofii.

To, co zwróciło moją szczególną uwagę, to fakt, iż większość tekstów skoncentrowanych jest wokół szeroko rozumianego problemu historii filozofii. Jan Patočka uważał, że dzieje filozofii nie mogą być rozumiane wyłącznie jako wstęp do filozofii, ale same w sobie są filozofowaniem. Nie może być dobrym historykiem filozofii ten, kto nie jest wpierw filozofem. Myślenie i jego dzieje stanowią jedność, która przybiera jedynie różne manifestacje tego samego. Większość zamieszczonych tu tekstów właśnie w kontekście filozofii dziejów pokazuje aktualność filozofii zarówno Kanta, jak i Husserla oraz Heideggera.

Na koniec trzeba dodać, iż poziom edytorski dzieła jest równie wysoki. Świadczą o tym między innymi zamieszczone na końcu książki zdjęcia z uroczystości wyręczania nagród prof. Sobotce i Münzowi. Posiadają one znakomitą jakość, nie są, jak ma to przeważnie miejsce w książkach naukowych, czarną plamą z zarysem postaci. Rzecz być może błaha, jednak świadczy o staranności edytorskiej.

Wreszcie, choć książka poświęcona jest w głównej mierze filozofii Kanta i jego recepcji, wszelako pozwala czytelnikowi zorientować się $\mathrm{w}$ nieco w meandrach filozofii słowackiej i czeskiej. Filozofii, której rodowód i charakter, podobnie jak ma to miejsce w przypadku filozofii polskiej, kształtował się głównie pod wpływem myśl niemieckiej. Niestety, wiedza o filozofii naszych południowych sąsiadów jest wciąż niewielka. Skoro tak, to nie pozostaje nic innego niż sięgnąć do tej słowackiej publikacji. 